\title{
Efficacy of Fungal Versus Bacterial Bioagents on Fusarium Wilt of Castor
}

\author{
Shalini Yerukala ${ }^{1 *}$, Vidya Sagar Bokka ${ }^{1}$, Giribabu Palaniappan ${ }^{2}$ and V. Krishna Rao ${ }^{1}$ \\ ${ }^{1}$ Department of Plant Pathology, College of Agriculture, Rajendranagar, \\ Hyderabad-500030, Telangana, India \\ ${ }^{2}$ Directorate of Oilseeds Research, Rajendranagar, Hyderabad- 500030, Telangana, India \\ *Corresponding author
}

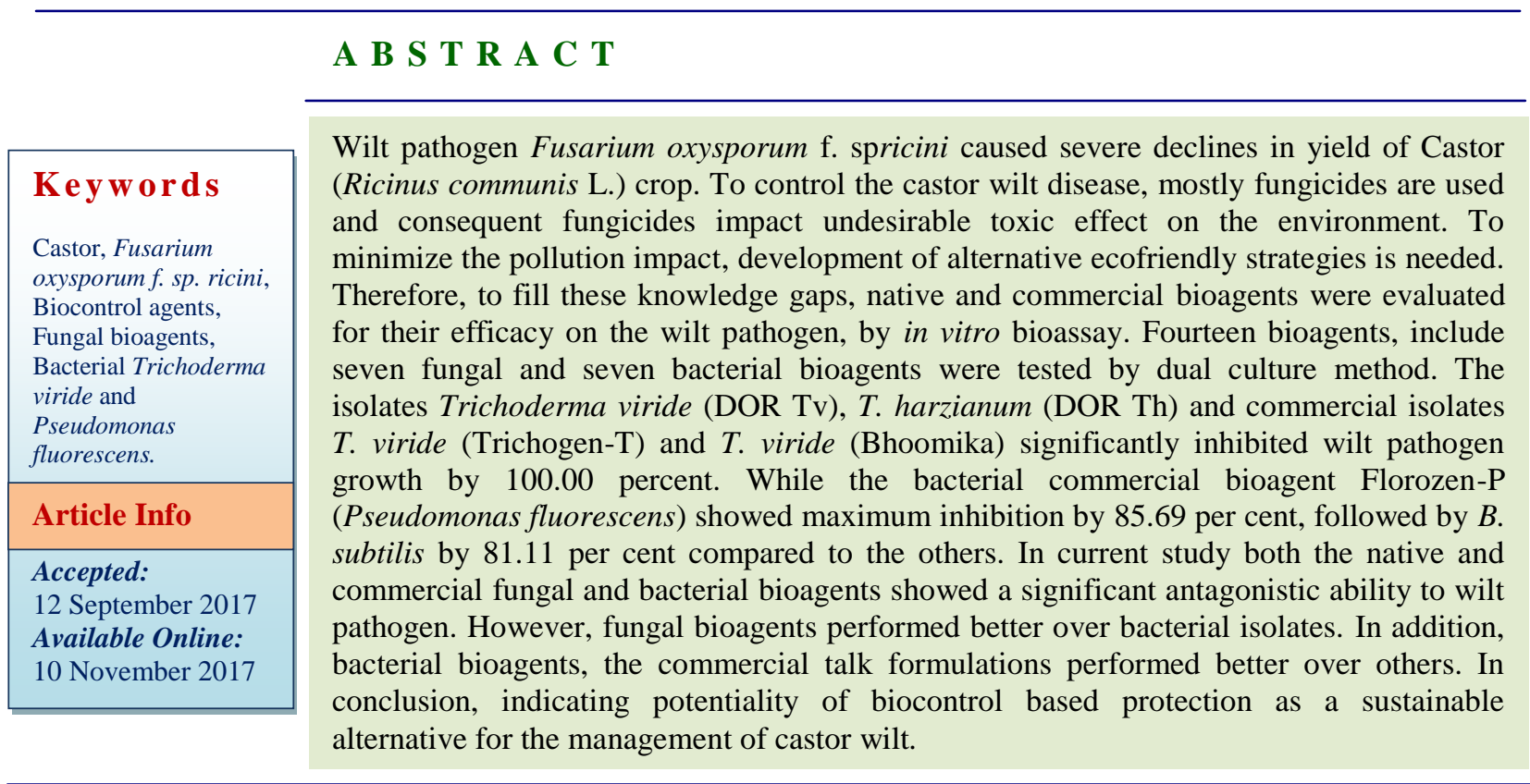

\section{Introduction}

Castor (Ricinus communis L.) which belongs to the family Euphorbiaceae is an important non-edible oilseed crop and plays a vital role in the Indian vegetable oil economy. The world's castor production is 15.4 lakh $\mathrm{m} \mathrm{t}$ (FAO, 2008). India ranks first in area (10.96 lakh ha) and production (11.43 lakh t) of castor in the world of which Gujarat, Rajasthan and Andhra Pradesh are major castor producing states. Andhra Pradesh accounts for 2.22 lakh ha with yield of 675 $\mathrm{kgha}^{-1}$ (INDIASTAT, 2013). The crop is extensively cultivated in Mahaboobnagar, Ranga Reddy, Nalgonda and Kurnool districts of the state. Wilt caused by Fusarium oxysporum $\mathrm{f}$. sp. ricini is a soil and seed borne pathogen colonizing the xylem vessels and blocking them completely causing heavy yield loss up to 85 percent, depending on fungal inoculum and environmental condition (Dange, 2003). Soil drenching with fungicides are generally used to control of castor wilt disease. However, frequent and in discriminant use of it, leads to ill effects on 
the environment, causing soil and water pollution and development of new pathogenic strains with more virulence. Hence biocontrol has been advocated as one of the promising alternative strategy to overcome these problems. Garrett (1956) defined biological control of plant diseases as "any condition under which or practice whereby, survival and activity of a pathogen are reduced through the agency of any other living organisms with the result that there is a reduction in the incidence of disease caused by the pathogen". In addition, many studies documented the antagonistic potentiality of Trichoderma sp. and Pseudomonas sp. Studies include Trichoderma spp. viz., Trichoderma harzianum, $T$. hamatum, $T$. viride, $T$. lignorum and $T$. koningii were tested against 19 isolates of $F$. oxysporum f.sp. carthami using the dual culture method and found that all the Trichoderma spp. inhibited the mycelial growth of the pathogen (Sunita and Datar, 2009); Trichoderma spp. effectively inhibited the growth of Rhizoctonia solani and $F$. solani which cause seedling disease of tomato (Rahman et al., 2001), also effective on forest nursery damping off fungi, $F$. oxysporum, $P$. aphanidermatum and $R$. solani (Sanjay and Kaushik 2001); on chickpea root rot causing pathogens $F$. oxysporium f.sp. ciceri, $R$. solani and Sclerotium rolfsii (Gupta et al.,2002). While the bacterial antagonist, $B$. subtilis showed maximum inhibition compared to $P$. fluorescens in controlling $F$. moniliforme (Karunakaran et al., 2003).

However, P. fluorescens strain 2P24 showed strong inhibitory activity against Ralstonia solanacearum, $F$. oxysporum and $R$. solani (Wei et al., 2004). Similarly, P. fluorescens showed promising antagonistic inhibition against $F$. oxysporum f.sp. vasinfectum, $F$. oxysporumf.sp. cubense, $R$. solani, Sclerotium rolfsii, Sarocladium oryzae and Aspergillus flavus and bacteria Xanthomonas campestris pv. citri and $X$. campestris pv. oryzae (Sakthivel et al., 1986). Also, effectively inhibited the growth of $F$. oxysporum f.sp. cicero (Vidyasekaran and Muthmilan, 1995); Curvularia lunata and Fusarium sp. (Rachana and Shalini, 2008). However, despite of many studies, there is a research gap exists in relation to native and commercial fungal and bacterial bioagents efficacy against wilt pathogen. Therefore, present study was conducted to investigate different efficacy rate of bacterial and fungal bio-agents. The best bioagents obtained could be potentially used to control castor wilt. We aimed to address the following issues: 1) Find out the best bioagent between native and commercially available formulation in the market effective against the $F$. oxysporumf.sp. ricini among tested 2. Suggestion or identification or recommendations of bioagent that could be economical for the farmers to manage the wilt disease.

\section{Materials and Methods}

All the experiments were carried out at Department of Plant Pathology, College of Agriculture, Rajendranagar, Hyderabad, India. Fourteen bioagents were procured from various sources presented in Table 1 (Figs. 1 and 2). Efficacy of these fungal and bacterial bioagents were evaluated against $F$. oxysporum f.sp. ricini under in vitro condition by using the dual culture method (Ambuse $e t$ al., 2012).

\section{Pathogenicity and re-isolation of test pathogen}

Pathogenicity of $F$. oxysporum f.sp. ricini was proved by adopting root dip inoculation technique. The surface sterilized seeds of the highly susceptible castor cultivar JI 35 were sown in pots filled with sterile potting mixture and watered regularly. For each isolate 50 seedlings were raised for proving 
pathogenicity. Ten-day old seedlings were uprooted, washed with sterile distilled water to remove the excess soil present on the root surface and distal one third of the root system was clipped. A total of 50 clipped seedlings were dipped in spore suspension for ten minutes and then transplanted back to the pots from where they were uprooted. Observations for the typical wilting symptoms were made up to six weeks after inoculation. The pathogen was re-isolated from infected seedlings and the culture obtained was compared with the original culture and was maintained on the PDA (Potato Dextrose Agar Medium), and was periodically sub cultured until use.

\section{Isolation of native fungal and bacterial bioagents (Table 1 and Fig. 1)}

The procured fungal cultures were maintained on PDA medium, and bacterial cultures on Nutrient Agar medium (NA). The inoculated plates were incubated at $28 \pm 2{ }^{\circ} \mathrm{C}$ for one week and were isolated and identified, and were used for further studies.

Isolation of commercial talk formulation of fungal and bacterial bioagents (Table 1 and Fig. 2)

\section{Fungal bioagents}

Talk formulation of $4 \mathrm{~g}$ was added to the 100 $\mathrm{ml}$ of sterile distilled water and $0.5 \mathrm{ml}$ of the preparation was aseptically transferred onto a PDA amended with streptomycin sulphate medium containing plates. The inoculated plates were incubated at $28 \pm 2{ }^{\circ} \mathrm{C}$ for one week and were isolated and identified and were used for further studies.

\section{Bacterial bioagents}

Talk formulation of $1 \mathrm{~g}$ was added to the 100 $\mathrm{ml}$ of sterile distilled water and $0.5 \mathrm{ml}$ of the preparation was aseptically transferred onto NA medium. The inoculated plates were incubated at $28 \pm 2{ }^{\circ} \mathrm{C}$ for 2 days and the resultant colonies were purified and used when necessary.

\section{Biocontrol agents}

Out of fourteen bioagents tested, seven fungal bioagents used, include four native and three commercial talk formulations. Out of seven bacterial bioagents, five include native and two commercials talk formulations. All the cultures were maintained on respective medium and were periodical transferred until used.

\section{Dual culture technique}

Culture discs $(5 \mathrm{~mm})$ of fungal antagonist and the test pathogen were cut with a sterilized cork borer from the edge of seven-day old culture and placed on the solidified medium (PDA) opposite to each other at equidistance. Whereas for bacteria, loopful of bacterial growth was streaked at one end of the petriplates containing PDA media, which was preinoculated with $5 \mathrm{~mm}$ mycelial discs of test pathogen at the other end of the petri-plate. For each treatment three replications were maintained. Suitable control was maintained by placing only the pathogen on the petiolate containing PDA. All The petri-plates were incubated at $28 \pm 2{ }^{\circ} \mathrm{C}$ and observed daily for recording antagonistic interactions between the pathogen and biocontrol agents.

The per cent growth reduction (R) of the test pathogen was calculated when the growth of the test pathogen was fully in control plates by using the formula given below.

$\mathrm{R}=(\mathrm{X}-\mathrm{Y}) / \mathrm{X} \times 100$

Where, (R) Per cent growth reduction of test pathogen, 
(X) Radial growth of test pathogen in control $(\mathrm{mm})$,

(Y) Radial growth of test pathogen in treatment $(\mathrm{mm})$

\section{Statistical analysis}

The experiment was Completely Randomized (CRD). The data obtained was transformed and was statistically analyzed using SAS-9.4 (SAS Institute, Cary, NC). Significant differences were further analyzed by the mean separation test by Least square means (LSD) (Tables 2 and 3 ).

\section{Results and Discussion}

The antagonistic effect of different bioagents (Table 1 and Figs. 1 and 2) was assessed based on their ability to inhibit the pathogen growth and development. Among fourteen tested bioagents, seven fungal bioagents tested against $F$. oxysporum f. sp. ricini (Figs. 3 and 5), the two-commercial isolates Trichogen-T T. viride (Sri Biotech Pvt. Ltd, Hyderabad.), $T$. viride (Bhoomika); two native isolates $T$. viride (DOR $\mathrm{Tv}$ ), $T$. harzianum (DOR Th), showed higher inhibition of wilt pathogen (100.00 percent) followed by Niprot (98.33 per cent), SAO TV (94.16 per cent) and ARI TV (79.16 per cent). While isolate ARI TV recorded least inhibition of test pathogen. Among the seven bacterial bioagents tested (Table 3 and Figs. 4 and 6) commercial bioagent Florozen-P Pf (Sri Biotech Pvt. Ltd, Hyderabad) inhibited 85.69 per cent of pathogen growth. Others include B. subtilis (Sri Biotech Pvt. Ltd, Hyderabad.) 81.11 per cent, ARI Pf (80.97per cent), DOR Bs(79.86 per cent), SAO Pf(73.33 per cent), DRR $\operatorname{Pf}(65.55$ percent) and DOR $\operatorname{Pf}(58.19$ per cent) showed significantly differences. It is evident from the data that all the antagonists studied significantly reduced fungal growth. However, the maximum inhibition (100 per cent) of $F$. oxysporum f.sp. ricini was observed by the commercial bioagents Trichogen- $T$, Bhoomika and native DOR Tv, DOR Th. The clear inhibition zone was also observed with all the fungal bioagents tested with a slight difference. However, the bacterial antagonists were inferior compared to the fungal antagonists tested in inhibiting the growth of the test pathogen. In the present study, different isolates of Trichoderma spp. (T. viride and $T$. harzianum) showed maximum and varied antagonist potential against the $F$. oxysporumf.sp.ricini. Possibly the antagonistic ability of Trichoderma sp., could be attributed by hyperparasitism, mycoparasitism, competition within the isolates or through production of antibiotics, which has already been well established and documented by Baker and Cook (1982) and Dubey (2000). Investigations on interaction of the plant pathogen and potential bioagents under in vitro condition throw light on possible mechanisms of antagonism such as mycoparasitism and production of diffusible antibiotics (Dennis and Webster, 1971).

Pioneering work of Weindling (1932), several successful attempts has been made to manage various soil borne fungi through biocontrol agents. In addition, the differences found in the efficacy of the various isolates of Trichoderma sp. may be due to their genetic makeup, as these may be from different ecological regions. In Trichoderma sp. in current research, $T$. viride and $T$. harzianum showed maximum inhibition against $F$. oxysporumf.sp.ricini. The findings of the present investigation are in agreement with Sunita and Datar (2009) who reported antagonistic potential of Trichoderma sp. in vitro against $F$. oxysporum f.sp. carthami, similar results were reported by Waghmare and Kurundkar (2011) against of $F$. oxysporum f.sp. carthami. Gupta et al., (2002) and Sunita and Kurundkar (2007) found the superiority of $T$. viride in the inhibition of $F$. oxysporum f.sp. ciceri, $R$. solani and Pythium 
aphanidermatum. The T. harzianum also showed maximum inhibition against $F$. oxysporum f.sp. riciniin the present study, the results are in accordance with Rahman et al., 2001, who reported the effectiveness of $T$. harzianum against $R$. solani and $F$. solani. Similar results were also reported by Karunakarna et al., 2003 against $F$. moniliformae.

Table.1 List of biocontrol agents screened against $F$. oxysporum f.sp. ricini

\begin{tabular}{|l|l|l|l|l|}
\hline S.No & $\begin{array}{l}\text { Tradename/ Culture } \\
\text { number }\end{array}$ & Bioagent & Formulation & Manufacturing company/ Source of supply. \\
\hline 1 & Trichogen-T Tv & T. viride & Talc & Sri biotech Pvt. Ltd Hyderabad. \\
\hline 2 & Florozen-P & P. fluorescens & Talc & Sri biotech Pvt. Ltd Hyderabad. \\
\hline 3 & Bacillus (Bs) & B. subtilis & Talc & Sri biotech Pvt. Ltd Hyderabad. \\
\hline 4. & DOR Tv & T. viride & culture & $\begin{array}{l}\text { Directorate of Oil Seeds Research, } \\
\text { Rajendranagar, Hyderabad. }\end{array}$ \\
\hline 5. & DOR Th & T. harzianum & culture & $\begin{array}{l}\text { Directorate of Oil Seeds Research, } \\
\text { Rajendranagar, Hyderabad. }\end{array}$ \\
\hline 6. & DOR Pf & P. fluorescens & culture & $\begin{array}{l}\text { Directorate of Oil Seeds Rearch, } \\
\text { Rajendranagar, Hyderabad. }\end{array}$ \\
\hline 7. & DOR Bs & B. subtilis & culture & $\begin{array}{l}\text { Directorate of Oil Seeds } \\
\text { Rajendranagar, Hyderabad. }\end{array}$ \\
\hline 8. & DRR Pf & P. fluorescens & culture & $\begin{array}{l}\text { Directorate of Rice Research, Rajendranagar, } \\
\text { Hyderabad. }\end{array}$ \\
\hline 9. & ARI Pf & P. fluorescens & culture & $\begin{array}{l}\text { ARI, Rajendranagar, Hyderabad. } \\
\text { ARI, Rajendranagar, Hyderabad. }\end{array}$ \\
\hline 10. & ARI Tv & T. viride & culture & $\begin{array}{l}\text { State Agriculture Office, Biological control } \\
\text { lab, Hyderabad }\end{array}$ \\
\hline 11. & SAO Tv & T. viride & culture & $\begin{array}{l}\text { State Agriculture Office, Biological control } \\
\text { lab, Hyderabad. }\end{array}$ \\
\hline 12. & SAO Pf & P. fluorescens & Talc & $\begin{array}{l}\text { Varsha Bioscience \& Technology India Pvt } \\
\text { Ltd.Hyderabad. }\end{array}$ \\
\hline 13. & Bhoomika & T. viride & Talc & $\begin{array}{l}\text { Pest Control (India) Private Limited, } \\
\text { Mumbai. }\end{array}$ \\
\hline 14. & Niprot & T. viride & Talc & \\
\hline
\end{tabular}

Table.2 Antagonistic activity of fungal biocontrol agents against $F$. oxysporum f. sp. ricini

\begin{tabular}{|r|l|c|c|}
\hline S.No. & $\begin{array}{l}\text { Fungal } \\
\text { Bioagent }\end{array}$ & $\begin{array}{l}\text { *Radial growth of } F . \\
\text { oxysporumf.sp. ricini }(\mathrm{mm})\end{array}$ & $\begin{array}{l}\text { *Per cent inhibition over } \\
\text { control }\end{array}$ \\
\hline 1 & Trichogen & 0 & $100 \mathbf{a}$ \\
\hline 2 & DORTv & 0 & $100 \mathbf{a}$ \\
\hline 3 & DORTh & 0 & $100 \mathbf{a}$ \\
\hline 4 & ARITv & 18.75 & $79.16 \mathbf{d}$ \\
\hline 5 & SAOTv & 5.25 & $94.16 \mathbf{c}$ \\
\hline 6 & Bhoomika & 0 & $100 \mathbf{a}$ \\
\hline 7 & Niprot & 1.5 & $98.33 \mathbf{b}$ \\
\hline 8 & Control & 90 & $0 \mathbf{e}$ \\
\hline & Mean & 14.43 & 83.95 \\
\hline
\end{tabular}

* Mean of three replications, means followed by the same letter in a column are non-significant, at 0.05 level of significance according to LSD. Highest mean is assigned the letter A 
Table.3 Antagonistic activity of bacterial biocontrol agents against $F$. oxysporum $\mathrm{f}$. sp. ricini

\begin{tabular}{|r|l|c|c|}
\hline S.No. & Bacterial Bioagent & *Radial growth of $F$. oxysporum f.sp. ricini $(\mathrm{mm})$ & *Per cent inhibition over control \\
\hline 1 & FlorozenP & 12.87 & $85.69 \mathbf{a}$ \\
\hline 2 & B. subtilis & 17 & $81.11 \mathbf{b}$ \\
\hline 3 & ARI Pf & 37.62 & $80.97 \mathbf{c}$ \\
\hline 4 & DORBs & 18.12 & $79.86 \mathbf{d}$ \\
\hline 5 & SAOPf & 31 & $73.33 \mathbf{e}$ \\
\hline 6 & DRRPf & 17.12 & $65.55 \mathbf{f}$ \\
\hline 7 & DORPf & 24 & $58.19 \mathbf{g}$ \\
\hline 8 & Control & 90 & $0 \mathbf{h}$ \\
\hline & Mean & 18.21 & 65.59 \\
\hline
\end{tabular}

*Mean of three replications, means followed by the same letter in a column are non-significant, at 0.05 level of significance according to LSD. Highest mean is assigned the letter A

Fig.1 Pure cultures of fungal biocontrol agents evaluated in the present study

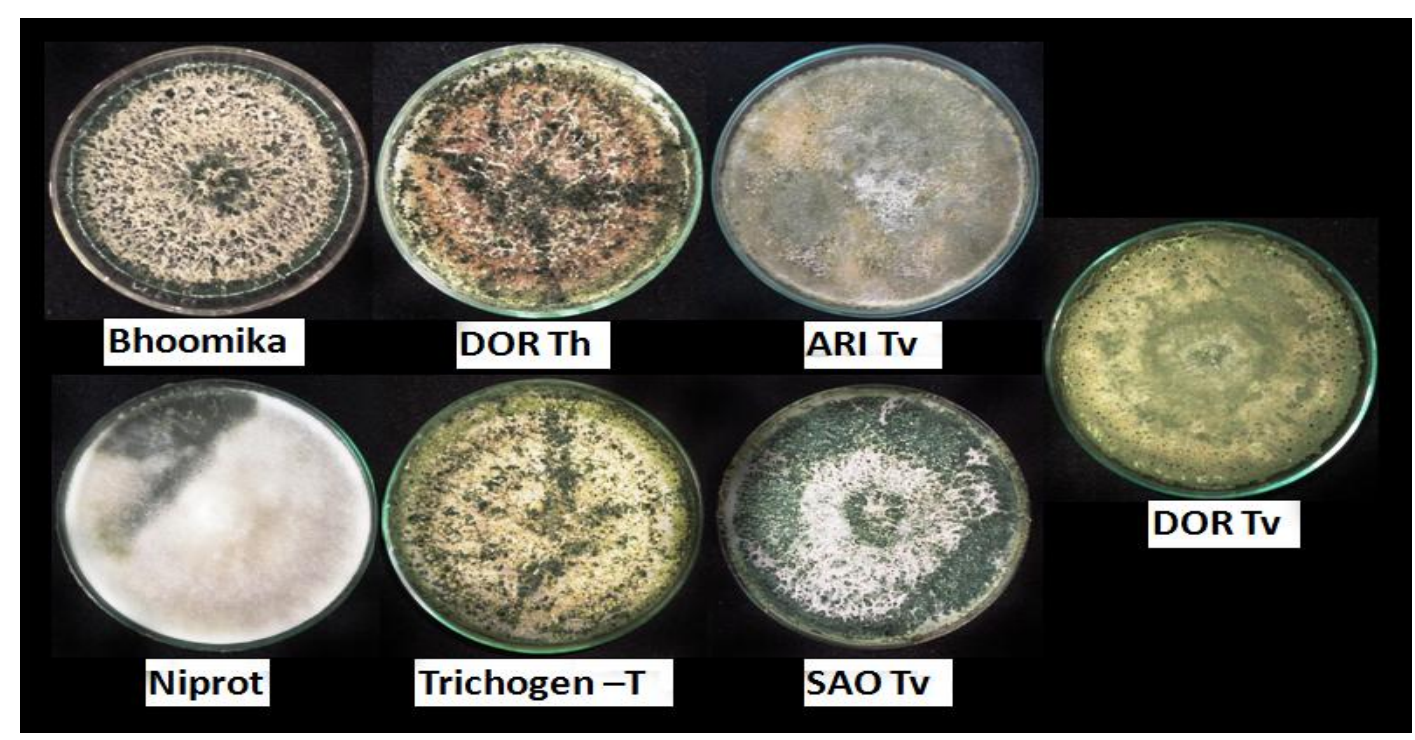

Fig.2 Pure cultures of bacterial biocontrol agents used in the present study

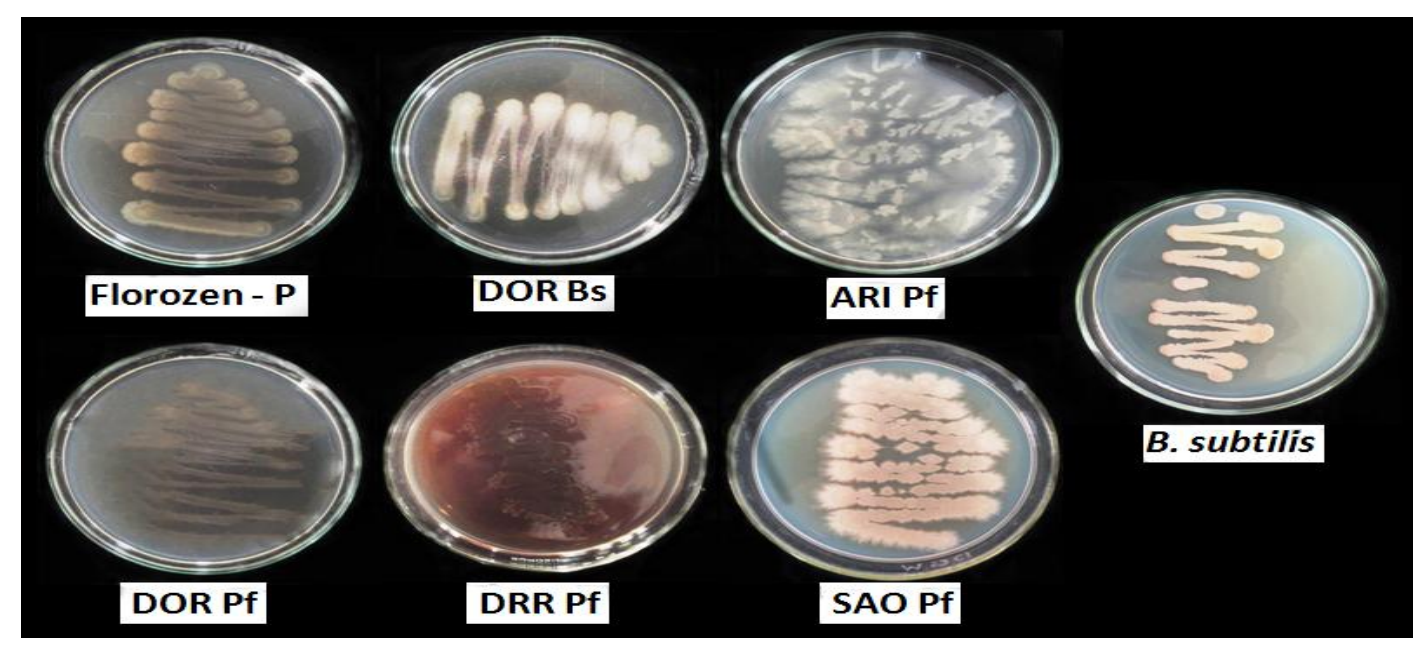


Fig.3 Antagonistic ability of fungal bioagents on radial growth of $F$. oxysporium f. sp. ricini

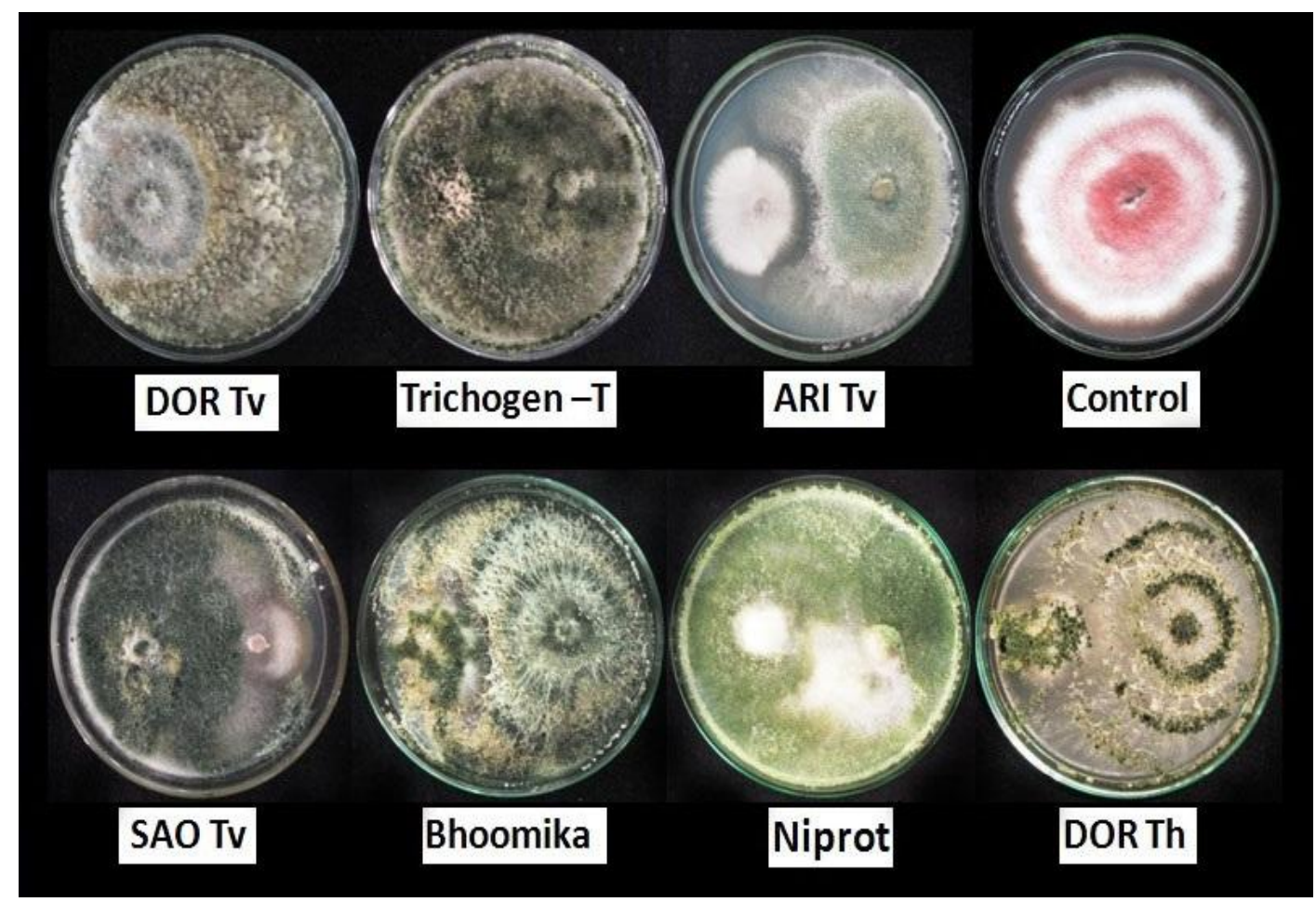

Fig.4 Antagonistic ability of bacterial bioagents on radial growth of $F$. oxysporium $\mathrm{f}$. sp. ricini

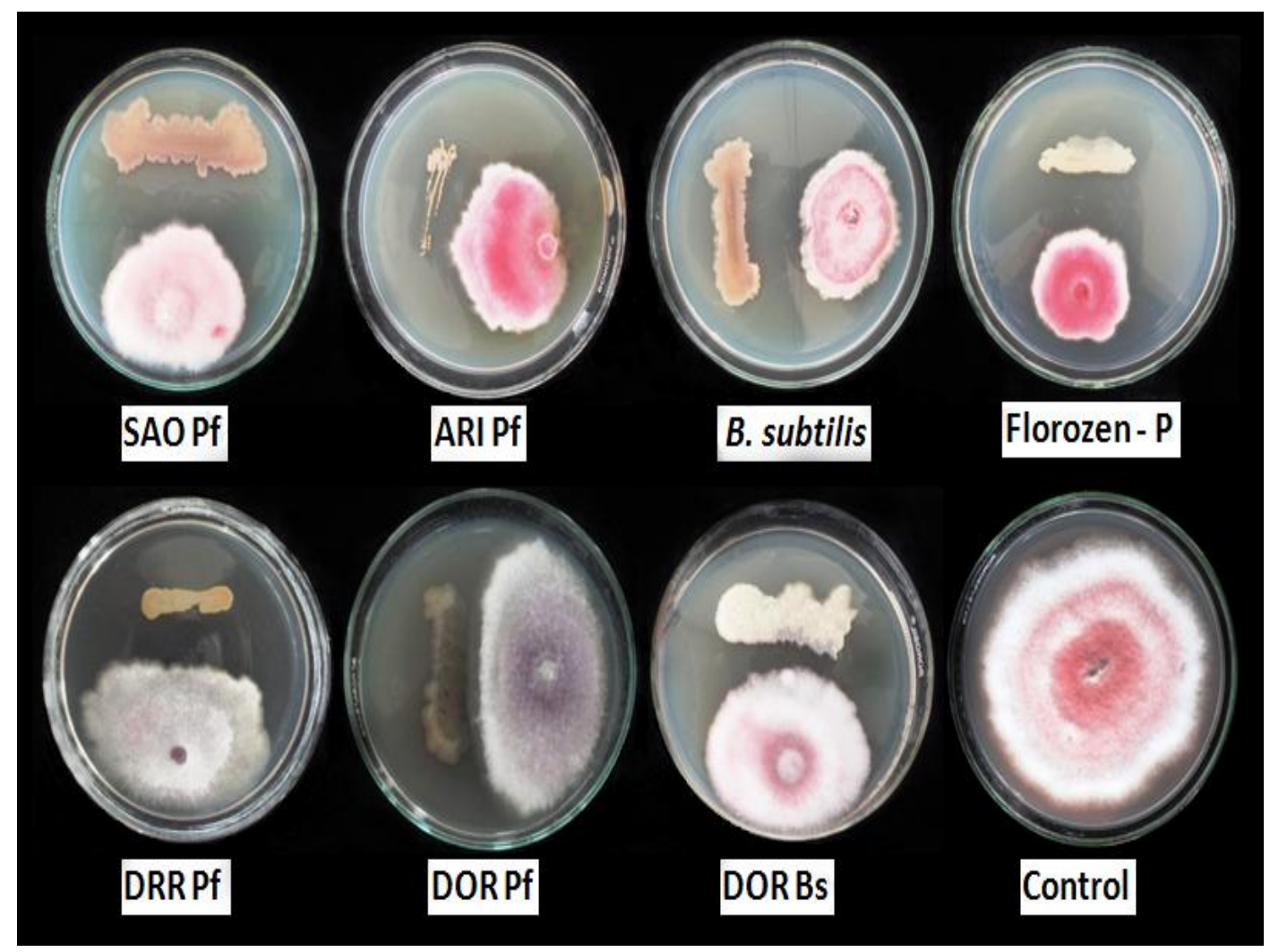


Fig.5 Efficacy of fungal bioagents on radial growth of $F$. oxysporum f. sp. ricini

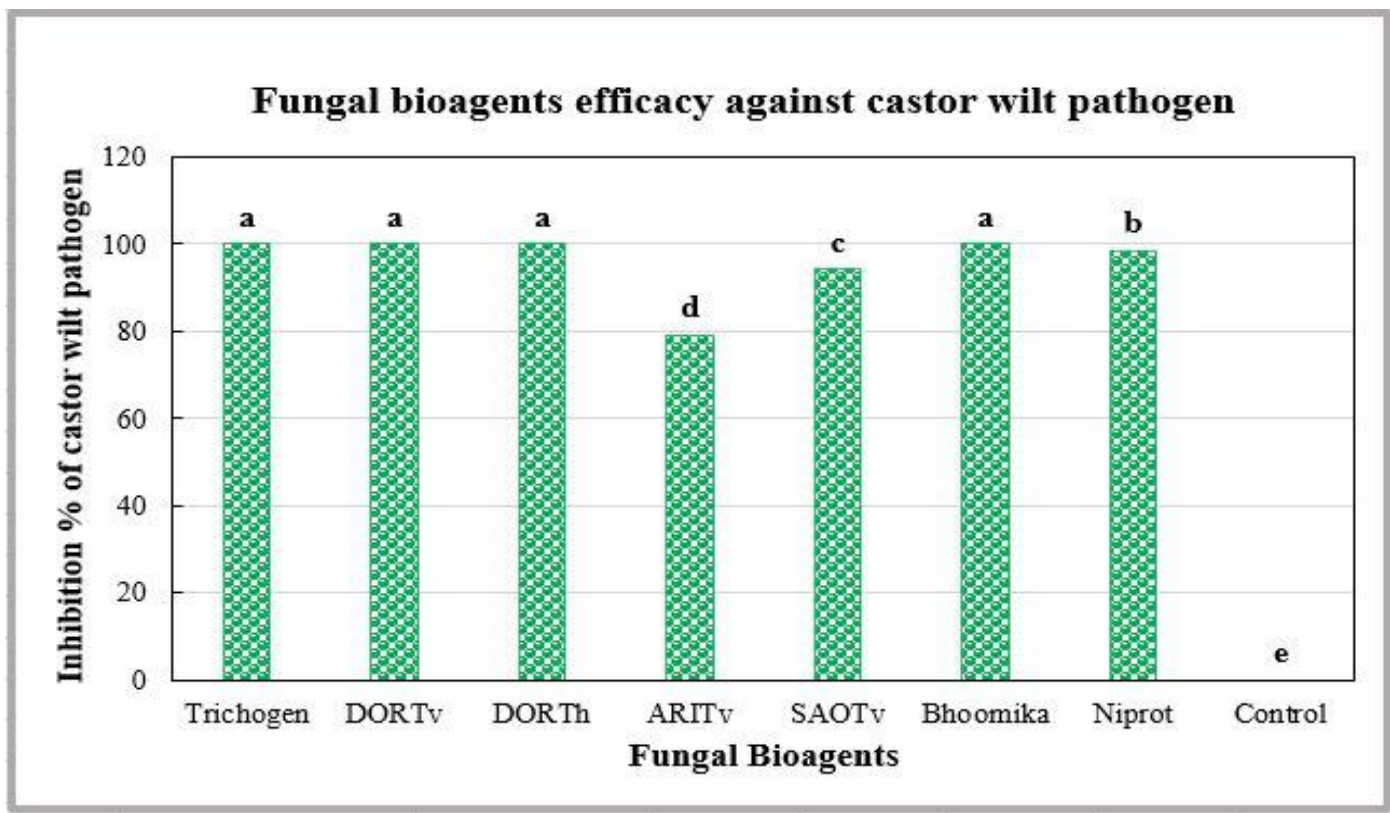

Fig.6 Efficacy of bacterial bioagents on radial growth of $F$. oxysporum $\mathrm{f}$. sp. ricini

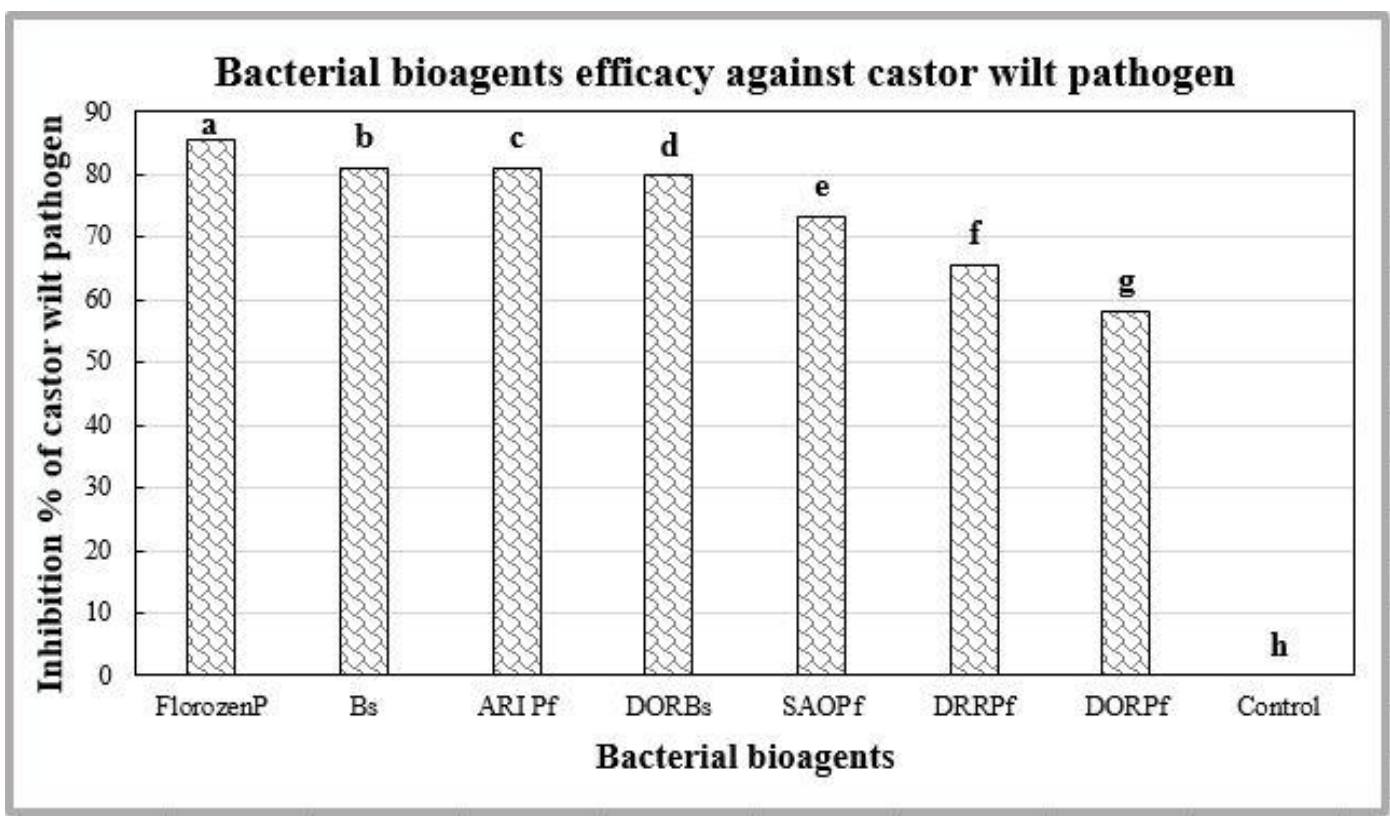

Among all bacterial isolates tested, $P$. fluorescens showed highest inhibition per cent against $F$. oxysporum f. sp. ricini. The antagonistic ability of $P$. fluorescens, mainly due to its ability to produce antagonistic compounds, such as antibiotics, siderophores, ammonia, cyanide and hydrolytic enzymes (Baker, 1987). Include, antibiotics like phenazine-1-carboxylic acid, pyoluteorin, acetyl-phlorolucinols. $P$. fluorescens also possibly known to produce hydrolytic enzymes, Indole 3-acetic acid (IAA) and 
Gibberlic acid (GA) and chemicals 2.4diacetyl phloroglucinol, pyrrolinitrin, pyoluteorin, siderophores, salicylic acid, hydrogen cyanide $(\mathrm{HCN})$ etc. which are possibly involved in its biocontrol activity. Voisardet al., 1989 also suggested that $P$. fluorescens have ability to synthesize hydrogen cyanide, which inhibit the pathogenic fungi and also to produce $\mathrm{HCN}$ that may be one of the causes of antagonism in $P$. fluorescens against plant pathogens. The findings of the present investigation are in agreement with the findings of Sakthivel et al., 1986 against $F$. oxysporum f.sp. vasinfectum, $F$. oxysporum f.sp. cubense. In current study, both the fungal and bacterial bioagents showed an effective antagonistic capacity against wilt phytopathogen. However, overall fungal bioagents performed better than bacterial bioagents. In addition, fungal commercial and native isolates performed on per with each other in reduction of wilt pathogen growth. While in bacterial isolates tested, the commercial talk formulations performed better over native bacterial isolates. Within bacterial bioagents tested, Pseudomonas sp. (Florozen-P Pf) performed better than Bacillus sp in control of castor wilt pathogen growth. Moreover, biocontrol agents have equal potential as fungicides for the reduction of pathogen growth as observed in the current study. In conclusion, in current study fungal bioagents include commercial bioagents Trichogen- $\mathrm{T}$, Bhoomika and native DOR Tv, DOR Th found to be best biocontrol agents in control of castor wilt pathogen $F$. oxysporumf.sp. ricini, that could be recommended for the farmers for the castor wilt disease control. Farmers could procure these commercial biocontrol formulations easily from the market either from local market or state agricultural offices. Hence biocontrol based protection could be a potent and sustainable alternative for the management of $F$. oxysporum f.sp. ricini.

\section{Acknowledgements}

The authors are grateful to the College of Agriculture, Rajendhranagar, Hyderabad, India for providing the financial assistance and support for conducting this research.

\section{References}

Ambuse, M.G., Chatage, V. S and Bhale, U. N. 2012. Influence of Trichoderma spp. against Alternaria tenuissima inciting leaf spot of Rumex acetosa L. Bioscience Discovery, 3(2), 259-262.

Baker, K.F and Cook, R.J. 1982. Biological control of plant pathogens. American Phytopathological Society. 453.

Baker, K.F. 1987. Evolving concepts of biological control of plant pathogens. Annual Review of Phytopathology. 25: 67-85.

Dange, S.R.S. 2003. Wilt of Castor-An overview. Indian Journal of Mycology and Plant Pathology. 33 (3): 333-339.

Dennis, C and Webster, J. 1971. Antagonistic properties of species groups of Trichoderma III hyphal interactions. Transactions of British Mycological Society. 57: 363-369.

Dubey N. K. 2000. Biological management of web blight of groundnut Rhizoctonia solani. Journal of Mycology and Plant Pathology. 30 (1): 89-90.

Food and Agriculture Organization (FAO). 2008.

Garrett, S.D. 1956. Biology of Root Infecting Fungi. Cambridge University Press, London. 29-30.

Gupta, S.B., Thakur, M.P., Tedia, K., Anup, K., Singh., Bachkaiya, K.K and Thakur, K. 2002. Studies on local isolates of Trichoderma viride and their relationship with wilt/root rot causing fungi of chickpea (Cicer arietimum L.). Journal of Mycology and Plant Pathology. 32(1-3):406. 
Indiastat. 2013. Crop statistics in India. www.indiastat.com/

Karunakaran, S., Prakasam,V., Merinbabu., Ladhalakshmi, D., Salah eddinkhabbaz and Sindhu, R.V. 2003. Effect of antagonists on Fusarium moniliforme Sheldon causing wilt disease in grapevine under glass house and field conditions. Annu. Meet and Symp. on Recent Developments in Diagnosis and Management of Plant Diseases for Meeting Global Challenges, Indian Phytopathological Society. 18-20 December 2003. 53.

Rachana and Shalini. 2008. Antifungal activity of Pseudomonas fluorescens against different plant pathogenic fungi. Electric Journal Environmental, Agricultural and Food Chemistry. 7 (4): 2789-2796.

Rahman, M.R., Faruk, M.P., Rahman, M.L., Begum, F and Bari, M.A. 2001. Suppression of tomato seedling disease by Trichoderma harzianum isolates. Bangladesh Journal of Plant Pathology. 17: $1-2$.

Sakthivel, N., Sivamani Anuratha, C.S. Savithiry, S and Gnanamanickam, S.S. 1986. Beneficial bacteria for plant disease management. Advances in research on plant pathogenic bacteria based on the proceedings of the National Symposium on Phytobacteriology. University of Madras, Madras, India. 14-15 March. 213-220.

Sanjay, A and Kaushik. 2001. Efficacy of Trichoderma species and Gliocladium virens as biocontrol agents against damping off of forest nurseries. Plant Disease Research. 16 (1): 46-51.

Sunita Waghmare, J and Datar, V.V. 2009. Biocontrol of Fusarium oxysporumf.sp. carthami by Trichoderma spp. Journal of Plant Disease Science. 4 (1): 134136.

SunithaWaghmare, $\mathrm{J}$ and Kurundkar, B.P. 2007. Efficacy of local isolates of Trichoderma spp. against Fusarium oxysporum f.sp. ciceri. Journal of Plant Disease Science. 2 (1): 48-50.

Vidhyasekaran, P and Muthamilan, M. 1995. Development of formulations of Pseudomonas fluorescens for control of chickpea wilt. Journal of plant Disease. 79: 782-786.

Voisard, C., Keek, C., Hars, D and Defago, G. 1989. Cyanide production by Pseudomonas fluorescens helps suppress black root rot of tobacco under gnotobiotic conditions. European Molecular Biology Organization Journal. 8: 351-358.

Waghmare, S.J and Kurundkar, B.P. 2011. Efficacy of local isolates of Trichoderma spp. against Fusarium oxysporum f. sp. carthami causing wilt of safflower. Advances in Plant Sciences. 24 (1): 37-38.

Wei, H., Wang Ye., Zhang liqun and Tang Wenhua. 2004. Identification and characterization of biocontrol strain 2P24 and CPF-10. Acta Phytopathologica Sinica. 34 (1): 80-85.

Weindling, R. 1932. Trichoderma lignorum as a parasite of other fungi. Phytopathology. 22: 837-845.

\section{How to cite this article:}

Shalini Yerukala, Vidya Sagar Bokka, Giribabu Palaniappan and Krishna Rao, V. 2017. Efficacy of Fungal Versus Bacterial Bioagents on Fusarium Wilt of Castor. Int.J.Curr.Microbiol.App.Sci. 6(11): 1230-1239. doi: https://doi.org/10.20546/ijcmas.2017.611.146 